\title{
Pengembangan Potensi Kepariwisataan Berbasis Masyarakat di Desa Pengkol, Kabupaten Sukoharjo, Jawa Tengah
}

\author{
Tular Sudarmadi
}

Prodi Pariwisata, Fakultas Ilmu Budaya, Universitas Gadjah Mada

Tim pengabdian kepada Masyarakat:

Tular Sudarmadi, Wiwik Sushartami, Arif Akhyat, Dwi Pradyawan, Bima Slamet Raharja

\begin{abstract}
Abstrak
Desa Pengkol secara administratif termasuk dalam Kelurahan Pengkol, Kecamatan Nguter, Kabupaten Sukoharjo, Jawa Tengah. Meskipun sudah tidak dikategorikan sebagai desa tertinggal, penghasilan yang diperoleh dari bercocok tanam sawah basah dan pencari ikan di dam Colo tetap belum dapat mencukupi sebagian besar kebutuhan hidupnya. Tidak mengherankan jika sebagian besar penduduk usia produktif lebih memilih untuk bekerja di pabrik-pabrik serta menjadi migran tenaga kerja buruh di negara-negara Singapura, Malaysia, Hongkong, dan Saudi Arabia. Pengamatan sekilas terhadap sumber daya alam, warisan budaya dan kehidupan sehari-hari menunjukkan bahwa Desa Pengkol dapat dikembangkan sebagai Desa Wisata yang pengelolaannya berbasis pada masyarakat. Atas dasar hal tersebut artikel ini menjelaskan upaya yang akan ditempuh dalam jangka pendek, menengah dan panjang untuk melakukan pendampingan, pengembangan, dan pengelolaan terhadap potensi wisata Desa Pengkol dengan tujuan akhir menjadikan Desa Pengkol sebagai Objek Daya Tarik Wisata berbasis masyarakat sehingga dapat meningkatkan kesejahteraan, baik ekonomi, sosial, dan budaya para warganya. Melalui upaya tersebut diharapkan para warganya tidak lagi menjadi migran untuk menjadi buruh, tetapi tetap tinggal di desa sebagai majikan yang mengelola sumber penghasilan yang diperoleh dari pertanian, penangkapan ikan, dan kunjungan wisatawan.
\end{abstract}

\begin{abstract}
Administratively, Pengkol Village is listed in Sub-district Pengkol, Nguter District, Sukoharjo Regency, Central Java. While this village is not categorized as a poor village, income earned from wet-field rice farming and fishing in Colo dam is not sufficient to support villagers' daily life. It is not surprising that most of the productive age population prefer to work in factory or as labor migrants in Singapore, Malaysia, Hong Kong and Saudi Arabia. A glimpse, of natural resources, cultural heritage and everyday life shows that Desa Pengkol can be managed as a Tourism Village Attraction. This article delineates the way in which Pengkol village is developed, managed, and empowered by short, middle and long community service program of the Community Based Tourism. Focusing on identification of tourism object attraction, this preliminary-short program-makes an effort to improve, not only the economic, social, and cultural, but also the villagers day to day life welfare. Given such efforts the Pengkol villagers are expected to stay during their productive age in their village as the owner and manager of tourism village attraction business. Further, they will not work as an industry worker or labor migrants.
\end{abstract}

Keywords: Pengkol Village, Community-based tourism, tourism development. 


\section{Pendahuluan}

Akhir-akhir ini para ahli pariwisata menyarankan industri pariwisata alternatif, yang mengakomodasikan pengelolaan industri pariwisata berskala kecil (small-scale tourism), bersifat lebih demokratis karena melibatkan masyarakat lokal dalam pengembangan dan pengelolaannya (community based tourism), sehingga dapat berkelanjutan (sustainable) program-programnya dan berupaya untuk mengentaskan kemiskinan masyarakat lokal (pro-poor tourism) (Holden, 2005, hlm.122-123; Beeton, 2006, hlm.79-104; Scheyvens, 2015; Jamal dan Dredge, 2015). Pengembangan industri di Casamance dapat dijadikan sebagai contoh penerapan model ini. 13 penginapan dibangun untuk para wisatawan dengan investasi awal sebesar 7.000 US dollar per penginapan. Modal diperoleh dari l'Agence de Cooperation Culturelle et Technique. Penginapan dibangun dengan bahan material lokal dan mengadaptasi bentuk rumah tradisional di kawasan tersebut. Jumlah wisatawan yang berkunjung dibatasi antara 20-40 orang, menu makanan mengikuti menu makanan lokal dan keuntungan yang diperoleh dari industri kecil pariwisata ini dikelola oleh dewan masyarakat lokal. Model ini ternyata berhasil meningkatkan kesejahteraan, menjaga stabilitas sosial masyarakat, perbaikan fasilitas kesehatan dan penambahan fasilitas pendidikan serta mencegah para pemuda dan pemudi bermigrasi ke kota.

Model pengelolaan seperti disebutkan sebelumnya dapat diterapkan untuk pengembangan pengelolaan industri pariwisata berskala kecil di Desa Pengkol, khususnya untuk meningkatkan kesejahteraan warganya. Desa Pengkol secara administratif terletak di Kelurahan Pengkol, Kecamatan Nguter, Kabupaten Sukoharjo bagian paling ujung berbatasan dengan Kabupaten Wonogiri. Saat ini Desa Pengkol berpenduduk 49.212 jiwa dengan luas wilayah desa: 366.3 ha, yang sebagian besar lahannya untuk sawah irigasi. Secara keseluruhan sawah di Desa Pengkol mendapat air dari Bendung/Dam Colo, salah satu pintu air utama dari waduk Gajah Mungkur. Keberadaan Dam Colo tidak hanya sebatas sebagai sumber pengairan sawah, melainkan juga sebagai tambahan penghasilan penduduk Desa Pengkol dari usaha menangkap ikan dan menjual peralatan penangkap ikan. Meskipun demikian, tingkat kesejahteraan dan taraf pendidikan penduduk Desa Colo masih memprihatinkan. Hal ini disebabkan pendapatan yang diperoleh dari hasil pertanian sawah basah dan perikanan tidak mencukupi untuk memenuhi kebutuhan hidup dan menyekolahkan anak-anak mereka. Sebagai akibatnya sebagian besar generasi muda merantau, baik ke luar desa untuk bekerja di pabrik-pabrik di sekitar kawasan Sukoharjo dan Solo maupun menjadi migran buruh di negara Malaysia, Singapura, Hongkong, dan Arab Saudi.

\section{Potensi Kepariwisataan Desa Pengkol}

Sampai saat ini penduduk Desa Pengkol belum menyadari bahwa sumber alam dan budaya di wilayah tempat tinggalnya memiliki potensi dan daya tarik wisata, yang dapat dikembangkan sebagai obyek daya tarik wisata (ODTW). Pemandangan alam saat matahari tenggelam di Dam Colo, sawah luas menghijau dengan pohon-pohon rindang, ternak kambing dan sapi yang digembalakan, kegiatan para petani bekerja di sawah, dan 
pertunjukan seni tradisi masyarakat agraris sekaligus pencari ikan merupakan atraksi wisata, yang memikat minat baik bagi wisatawan mancanegara maupun wisatawan nusantara (yang hidup di perkotaan) untuk berkunjung, tinggal sementara, menikmati keindahan alam, dan merasakan (experiencing) kehidupan sehari-hari masyarakat pedesaan. Pengenalan dan pemahaman penduduk Desa Pengkol terhadap potensi alam dan budaya sebagai daya tarik wisata tentu saja sangat bermanfaat sekali untuk mengembangkan wilayah desa mereka sebagai obyek daya tarik wisata, yang dapat menghasilkan uang dari hasil pengelolaannya. Adanya penghasilan tambahan tersebut tentu saja akan meningkatkan taraf hidup mereka sehingga diharapkan di masa depan kehidupan mereka akan semakin sejahtera.

\section{Peran Akademisi dalam Pengembangan Potensi Kepariwisataan Desa Pengkol}

Sebagai upaya untuk memberdayakan warga Desa Pengkol agar dapat menemukenali, mengelola, mengembangkan, dan melestarikan potensi kepariwisataan yang ada di desa tersebut, tim pengabdian kepada masyarakat dari Fakultas Ilmu Budaya yang memiliki kompetensi terhadap pengenalan, pemanfaatan dan pengelolaan sumber daya alam, warisan budaya, serta kepariwisataan tertarik untuk menyumbangkan kepakarannya guna meningkatkan taraf kesejahteraan penduduk di wilayah Desa Pengkol. Program Pengabdian Masyarakat tim dari Fakultas Ilmu Budaya bertujuan untuk melibatkan partisipasi seluruh warga desa dalam mengembangkan Desa Pengkol sebagai Desa Wisata salah satu objek daerah tujuan wisata di Propinsi Jawa Tengah, khususnya di Kabupaten Sukoharjo.

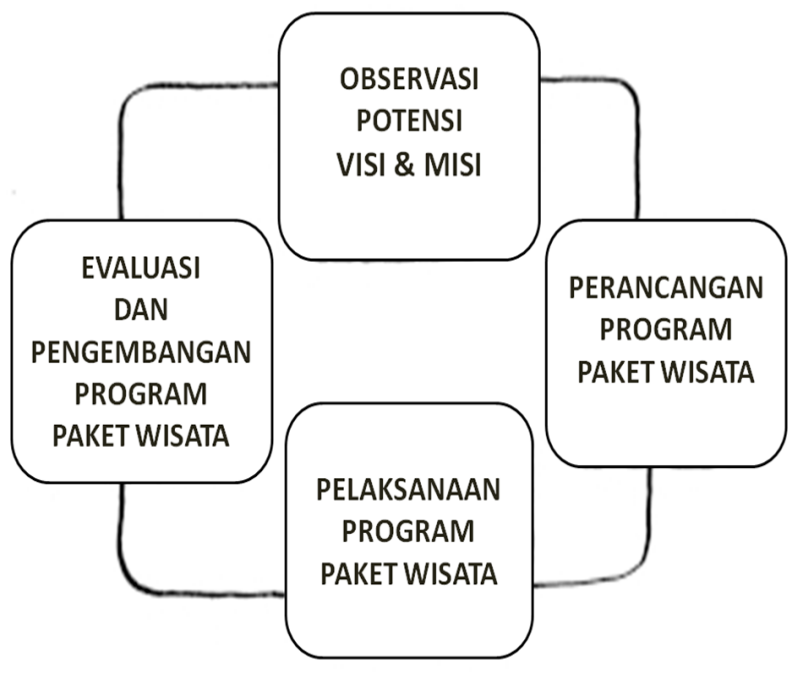

Diagram 1. Tahapan dan Model Pengembangan Potensi Kepariwisataan Desa Pengkol

Pada dasarnya pengembangan Desa Pengkol sebagai Desa Wisata yang melibatkan masyarakat dalam setiap tahapan dan proses pelaksanaannya memerlukan jangka waktu 
yang lama. Hal ini disebabkan oleh sumber dana yang terbatas, sumber daya manusia yang perlu ditingkatkan kemampuannya, dan perlunya pendampingan serta pengambilan keputusan yang lebih bersifat musyawarah untuk mencapai mufakat. Atas dasar hal tersebut pelaksanaan program Pengabdian Masyarakat akan dilaksanakan dalam empat tahap yang diadaptasi dari The Mountain Institute (2000, hlm. 17) sebagaimana terlihat dalam diagram 1:

Masing-masing tahap akan dilakukan dalam jangka waktu satu tahun. Program di tahun pertama akan dilakukan mulai pada bulan Agustus 2017, yang berupa observasi potensi sumber daya alam, warisan budaya, atraksi wisata serta diteruskan dengan kegiatan focus group discussion dengan para dosen Fakultas Ilmu Budaya yang terlibat dalam kegiatan pengabdian ini, warga Desa Pengkol, dan para stake holder. Tahun ke dua akan diselenggarakan pada bulan Agustus 2018, yang berupa perancangan serta pembuatan program paket wisata, promosi, dan pemasaran. Tahun ke tiga akan dilanjutkan pada bulan Agustus 2019 dengan program pelaksanaan program paket wisata. Tahun ke empat akan dilakukan pada bulan Agustus 2020 dengan kegiatan evaluasi dan pengembangan program paket wisata.

Artikel ini menguraikan program pengabdian masyarakat tahap pertama (jangka pendek) di Desa Pengkol, Kecamatan Nguter, Kabupaten Sukoharjo, Jawa Tengah. Strategi pengembangan kepariwisataan di tahap awal menerapkan pola penalaran induktif. Dalam hal ini pengamatan diawali terhadap sumber daya alam, sumber daya budaya, warisan budaya dengan pendekatan yang mengutamakan partisipasi dan keterlibatan masyarakat. Selanjutnya hasil pengamatan yang ditemukan akan didiskusikan secara bersama-sama antara tim pengabdian masyarakat, warga Desa Pengkol, dan para stake holder dalam forum focus group discussion. Tahap akhir dari diskusi adalah pembentukan kelompok sadar wisata di Desa Pengkol dan menetapkan visi serta misi program Desa Wisata Pengkol. Sesuai dengan pola penalaran induktif tersebut, strategi penelitian yang diterapkan adalah strategi penelitian deskriptif-analitik. Tahapan dalam strategi ini adalah:

\section{Pengumpulan data}

Data yang dikumpulkan berupa profil wilayah dan objek-objek yang berpotensi untuk dikembangkan sebagai tujuan wisata di Desa Pengkor. Selain itu akan dikumpulkan pula informasi yang berkaitan dengan sarana, prasarana, aspek sosial, ekonomi dan budaya. Perolehan data tersebut berasal dari sumber primer, yang didapatkan dari hasil observasi ke wialayah Desa Pengkol dan wawancara terhadap stake holder di bidang kepariwisataan selama 3 hari. Data dari sumber primer juga diperkuat dengan data sekunder yang diperoleh dari referensi-referensi yang berhubungan dengan artikel, buku dan sumber-sumber tertulis tentang kesejarahan wilayah Sukoharjo, monografi Desa Pengkol, penelitian objek kekunoan di Kabupaten Sukoharjo serta daftar objek wisata di kawasan Kabupaten Sukoharjo.

\section{Analisis data}

Data primer dan data sekunder yang sudah terkumpul, kemudian akan dikelompokkan sesuai dengan tujuan kegiatan, yaitu mengidentifikasi kelayakan objek wisata di kawasan Desa Pengkol. Sebagai contoh, pengelompokan akan menghasilkan objek wisata alam, 
objek wisata budaya, dan objek wisata minat khusus. Selanjutnya data yang sudah dikelompokkan akan direlasikan dan disintesakan dengan data keadaan sosial, ekonomi dan budaya Desa Pengkol. Selain itu hasil dari pengelompokan, penghubungan dan penggabungan data akan ditelaah dengan variable persyaratan yang harus dimiliki oleh objek daya tarik wisata, yaitu atraksi, yang diperinci lagi menjadi sesuatu yang dapat dilihat (something to see), sesuatu yang dapat dilakukan (something to do) dan sesuatu yang dapat dibeli (something to buy); amenitas, aksesibilitas dan ansiliari. Keseluruhan proses analisis ini dibingkai dalam paradigma eko wisata (ecotourism), pariwisata berkelanjutan (sustainable tourism), dan parawisata berbasis masyarakat (community based tourism). Hal ini berarti, setiap atraksi fasilitas, aksesibilitas dan ancilery harus memenuhi kaidah ketiga paradigma tersebut, yaitu mengutamakan pelestarian keindahan dan sumber daya alam, yang dilakukan secara berkelanjutan dan melibatkan partisipasi masyarakat dalam pelaksanaannya sehingga mereka memperoleh keuntungan ekonomis, budaya dan sosial dari hasil pengembangan kepariwisataan yang ada di kawasan Desa Pengkol.

\section{Temuan Potensi Kepariwisataan Desa Pengkol}

Desa Pengkol secara geografis terletak pada koordinat 7043’44,563" LS - 7045'9,987” LS dan $110^{\circ} 53^{\prime} 32,28^{\prime \prime}$ BT - 110 ${ }^{\circ} 55^{\prime} 1,259$ BT” serta berjarak lebih kurang 737 meter dari Bendungan Colo. Terletak di dataran rendah dengan ketinggian dari permukaan air laut 144-140 meter. Secara administratif Desa Pengkol termasuk dalam wilayah Kalurahan Pengkol, Kecamatan Nguter, Kabupaten Sukoharjo, Propinsi Jawa Tengah. Luas keseluruhan Desa Pengkol 266,2520 Ha di bagian utara dibatasi oleh Desa Clep, di bagian selatan dibatasi oleh Kabupaten Wonogiri, di bagian barat dibatasi oleh Desa Gupit, dan di bagian timur dibatasi oleh Desa Jangglengan. Luas wilayah desa yang diperuntukkan bagi perumahan 128,8070 $\mathrm{Ha}$, sawah 113,2520 $\mathrm{Ha}$, tegal 33,2785 $\mathrm{Ha}$, tanah kas desa, pemakaman desa, dan lain-lainnya seluas 85,9195 Ha. (Monografi Desa Pengkol, 2016, hlm. 1-3).

Saat ini jumlah penduduk Desa Pengkol pria sebanyak 2055 orang dan wanita sebanyak 1894 orang. Sebagian besar mereka bekerja sebagai petani, buruh tani, dan lainnya bekerja sebagai pegawai negeri sipil, TNI/Polri, buruh industri, dan pedagang. Pendidikan sebagian besar warga desa baru mencapai tingkat Sekolah Dasar dan Sekolah Menengah Pertama, hanya sebagian kecil saja yang menyelesaikan pendidikan hingga Perguruan Tinggi. Pada umumnya pemuda warga Desa Pengkol mengembara ke kotakota besar dan mencari lapangan pekerjaan informal, antara lain sebagai penjual bakso, mie ayam, dan sebagai pembantu rumah tangga (Ibid).

Sesungguhnya Desa Pengkol belum terlalu lama keberadaannya. Sekitar tahun 1965-an Desa Pengkol terletak di kelokan Sungai Bengawan Solo dan akibat banjir besar yang melanda desanya, pemerintah kemudian memindahkan penduduk Desa Pengkol ke tempat desa baru sekarang ini. Di lokasi wilayah baru tersebut, juga dihuni oleh warga desa pindahan dari Desa Bangunsari dan Desa Pending. Meskipun kemudian mereka bersedia pindah ke lokasi yang baru, tetapi saat mereka bermufakat dengan kedua warga dukuh pindahan lainnya, warga Desa Pengkol yang paling banyak jumlah warganya bersikeras tetap mempertahankan nama desa 'Pengkol', yang berarti desa di kelokan atau tikungan Sungai Bengawan Solo. Nama baru desa pindahan tersebut (bedhol deso) 
kemudian disepakati oleh seluruh warga desa yang bermufakat dan sampai saat ini nama itu tetap lestari.

\section{Potensi Atraksi Wisata Desa Pengkol}

Hasil observasi terhadap wilayah Desa Pengkol menunjukkan adanya potensi wisata yang dapat menarik para wisatawan untuk berkunjung, tetapi potensi tersebut belum dikembangkan dan dikelola dengan baik oleh para warga desanya. Potensi tersebut antara lain adalah bangunan bendung/dam Colo, persawahan, pemandangan alam, serta kehidupan sehari-hari warga desa, antara lain, menanam padi di sawah, menggembala sapi \& kambing, memancing ikan, menjala ikan, menyamber ikan, dan membuat jala ikan. Seluruh observasi yang dilakukan dapat dilihat pada peta berikut ini

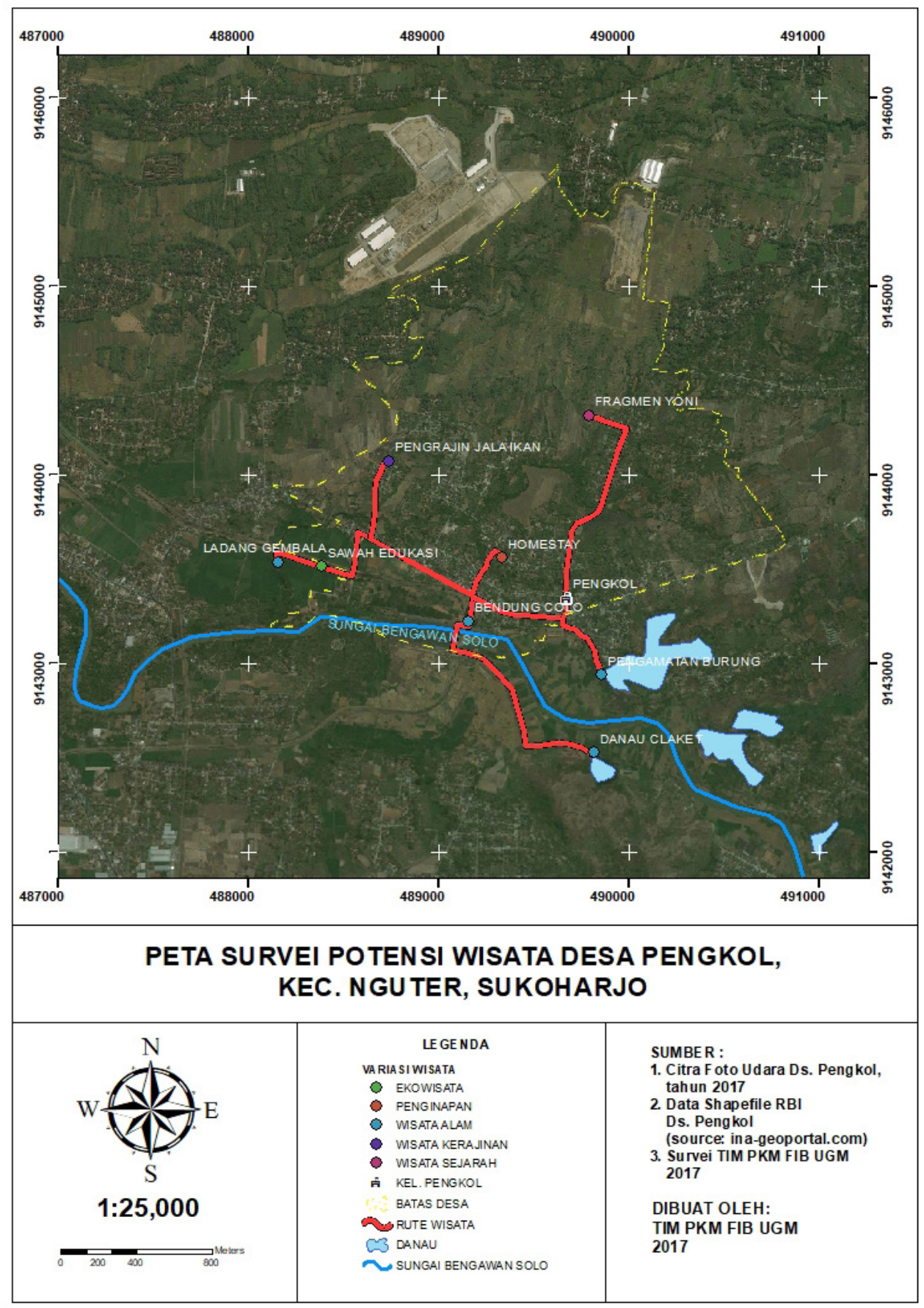




\section{Bendung/dam Colo}

Bendung Colo merupakan salah satu bangunan pintu air besar dari waduk Gajah Mungkur, Wonogori, yang berfungsi untuk mengalirkan serta membagi air untuk mengairi persawahan di Kabupaten Sukoharjo. Lokasi bendung tersebut terletak di Desa Pengkol, Dusun Ngemplak, RW 1, RT 3. Selain bentuk arsitektur bangunan bendung yang menarik untuk dilihat, pemandangan sepanjang kanan kiri bendung juga sangat indah. Persawahan yang luas menghijau, pepohonan besar dan rindang, serta pegunungan yang tampak dikejauhan menjadikan lokasi tersebut sangat mempesona untuk dikunjungi. Terlebih lagi pada saat matahari tenggelam, puncak tiang jembatan akan tepat berada di titik kulminasi terbenamnya matahari. Selain itu, deretan struktur segi empat yang ada di bagian bawah bendung, air yang mengalir, dan pegunungan dikejauhan akan menarik sekali sebagai latar belakang saat pengunjung berselfie. (periksa foto $1,2,3)$

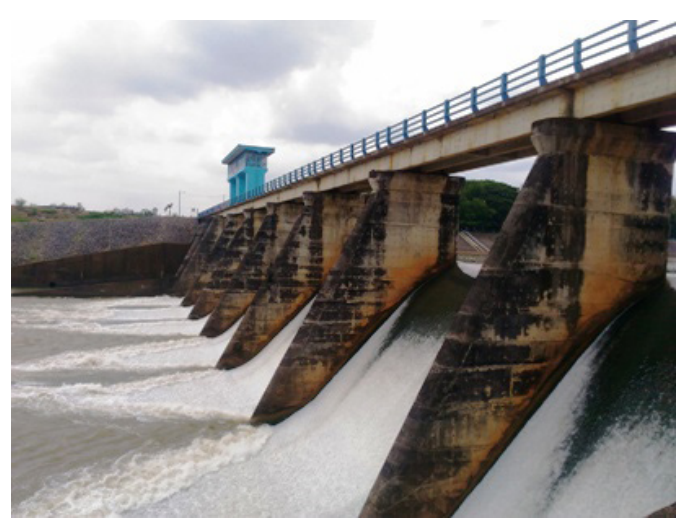

Foto 1. Pintu air Bendung Colo (Tim PKM Pengkol)

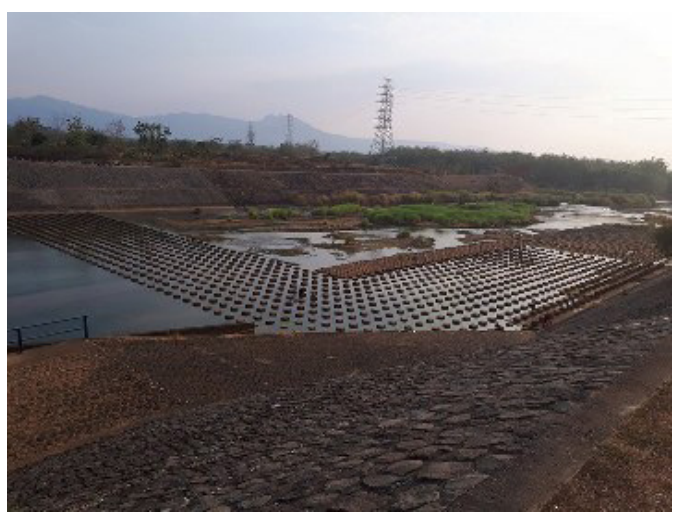

Foto 2. Struktur Bendung Colo (Tim PKM Pengkol)

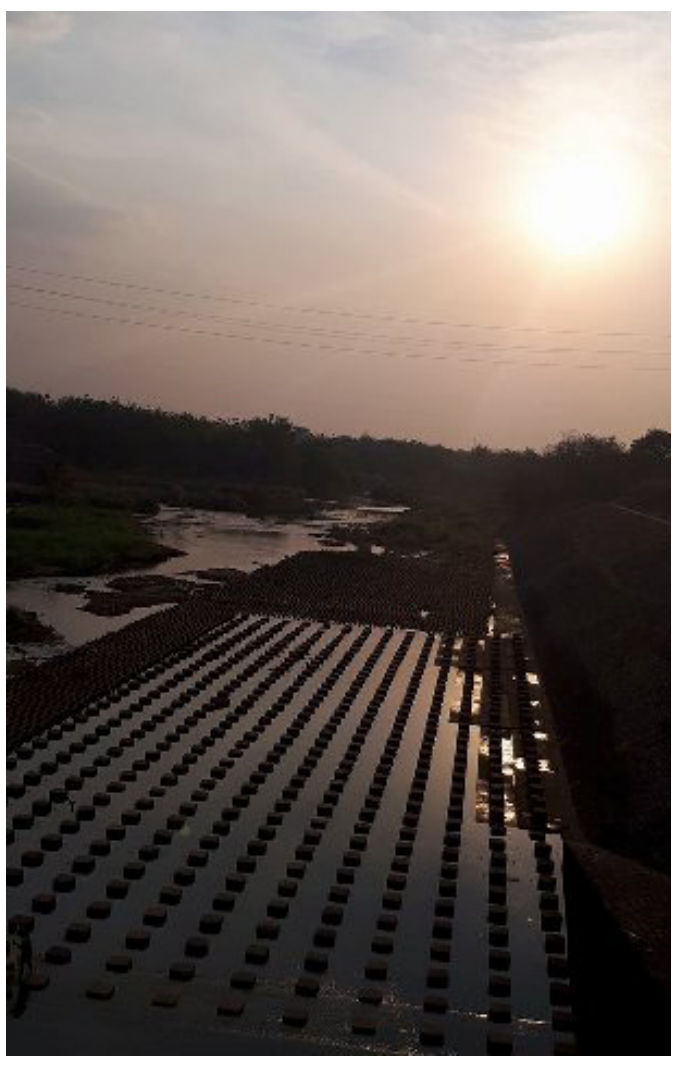

Foto 3. Matahari terbenam di Bendung Colo (Tim PKM Pengkol) 
Selama melihat pemandangan dan menunggu matahari tenggelam pengunjung juga dapat bersantai di warung-warung bangunan sederhana sambil menikmati kuliner khas Sukoharjo, yaitu pecel gendar, bakso, dan mie ayam. Dan kuliner ala barat, antara lain kentang goreng, sosis bakar. Warung-warung tersebut terletak di bantaran Bendung Colo. Bagi yang suka berolahraga dapat juga berjalan-jalan atau berlari di sepanjang pinggiran Bendung Colo sambil menikmati keindahan pemandangan alam di sekitar bantaran Bendung Colo (foto 4).

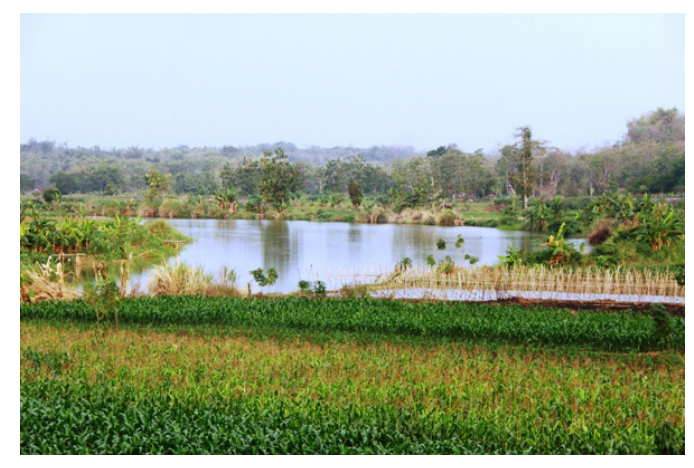

Foto 4. Pemandangan alam di sepanjang bantaran Bendung Colo (Tim PKM Pengkol)

\subsubsection{Persawahan}

Desa Pengkol yang terletak di dataran rendah memiliki hamparan persawahan luas. Salah satu areal persawahan yang memiliki keindahan alam yang sangat indah terletak di Dusun Pending, RW 1, RT 1. Tepat di sebelah areal persawahan tersebut terdapat bangunan parit selokan besar yang dipakai untuk menyalurkan air dari Bendung Colo. Pada saat pagi hari pengunjung dapat melihat kegiatan bercocok tanam mulai dari membajak sawah, menanam benih padi, memberi pupuk, membersihkan gulma tanaman padi, dan memanen padi. Seringkali rombongan bangau beterbangan di sekitar persawahan dan mencari katak, kadal dan ikan-ikan kecil (periksa foto 5). Menjelang sore, pengunjung akan melihat warga desa mencari rumput untuk makanan ternak, menggembalakan ternak, dan memandikan ternaknya.

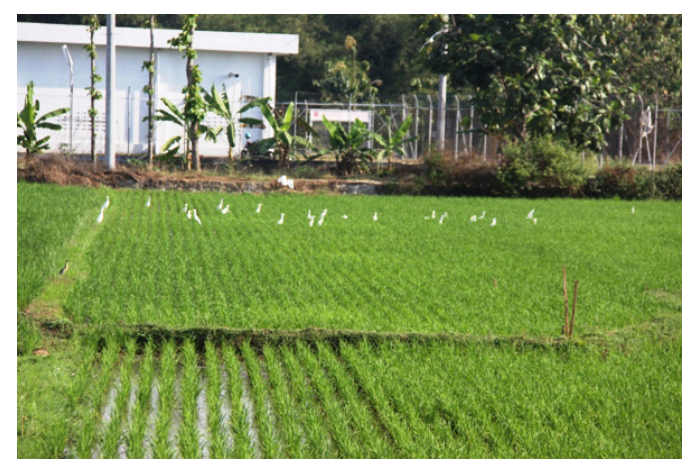

Foto 5. Burung bangau mencari makan di sawah (Tim PKM Pengkol) 
Areal persawahan lainnya yang sangat menarik dikunjungi saat sore hari terletak di Dusun Tanjung Rejo RW, RT Menjelang petang, sekitar pukul empat sore kawanan bangau dari berbagai tempat akan mendatangi areal persawahan tersebut dan berkumpul serta mencari makan hingga saat matahari mulai terbenam. Satu persatu mereka terbang meninggalkan areal persawahan, sebelum akhirnya membentuk rombongan burung bangau dan bersama-sama terbang ke sarang mereka. Pada saat itu pula pengunjung dapat menyaksikan terbenamnya matahari di balik perbukitan yang berbentuk seperti orang tidur telentang. Sementara itu di langit semburat merah senja diselang-seling dengan kawanan burung bangau kembali kesarangnya (periksa foto 6, 7, 8). Atraksi keindahan alam seperti ini sukar untuk dilewatkan begitu saja tanpa membuat foto-foto dan selfie

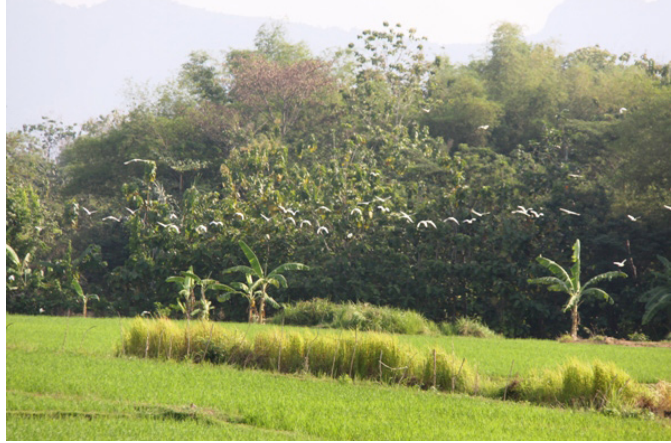

Foto 6. Rombongan burung bangau pullang ke sarang (Tim PKM Pengkol)

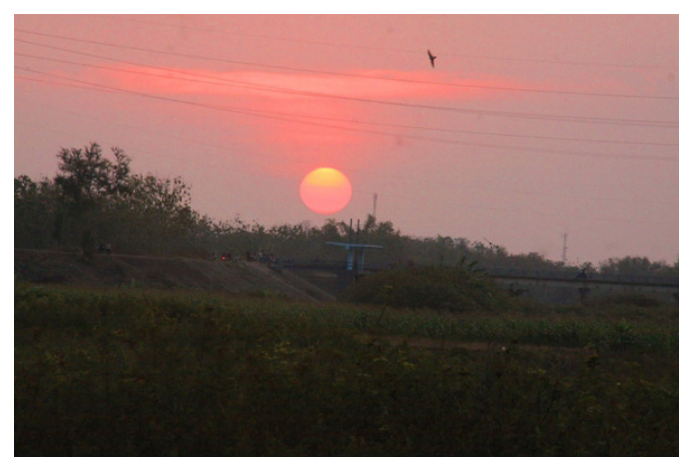

Foto 7. Matahari terbenam di persawahan Desa Pengkol (Tim PKM Pengkol)

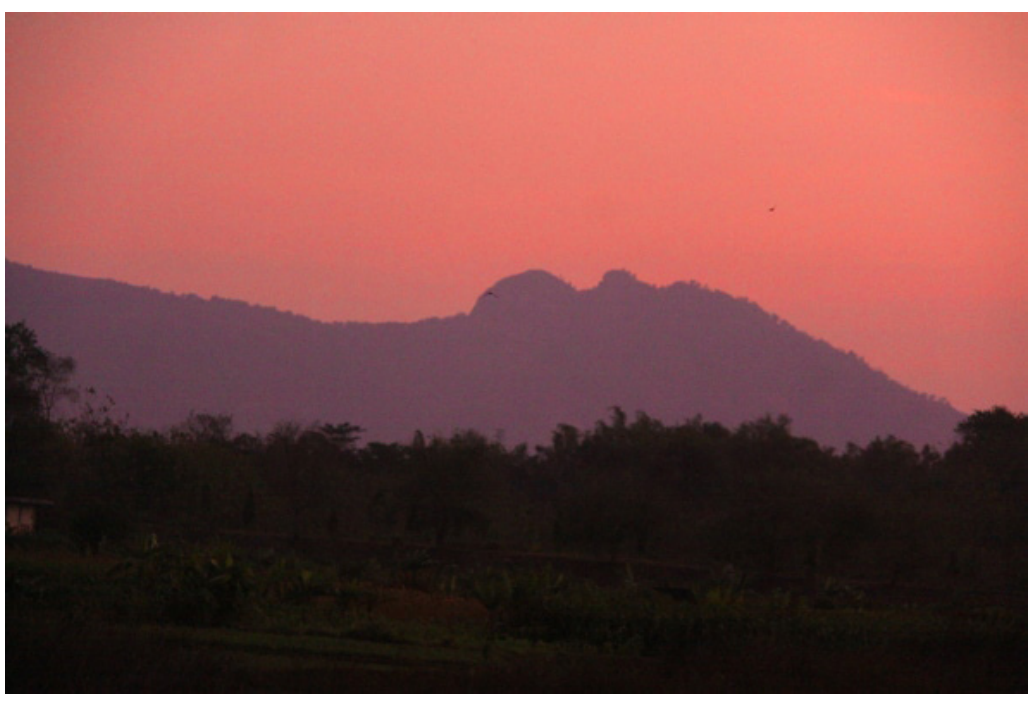

Foto 8. Kala senja di bukit berbentuk manusia tidur telentang (Tim PKM Pengkol) 


\section{Saluran Irigasi}

Saluran irigasi di Desa Pengkol juga dapat dijadikan sebagai atraksi wisata. Berjalan di sepanjang salurannya pengunjung dapat melihat keindahan alam, teknis konstruksi pengairan, dan kegiatan warga desa mengerjakan sawah, menggembala ternak, menjaring, menjala, mengail serta menciduk ikan (periksa foto 9). Hasil tangkapan ikan yang diperoleh juga beraneka ragam jenisnya, yaitu ikan sepat/gurami (Trichogaster), ikan wader (Rasbora argyrotaenia), ikan gabus/kutuk (Channa striata), udang (Cambarus virilis), ikan mas (Cyprinus carpio), dan ikan nila (Oreochromis niloticus). Pengunjung juga dapat membeli secara langsung hasil ikan tangkapan segar warga desa dan mencoba menjaring serta menciduk ikan.

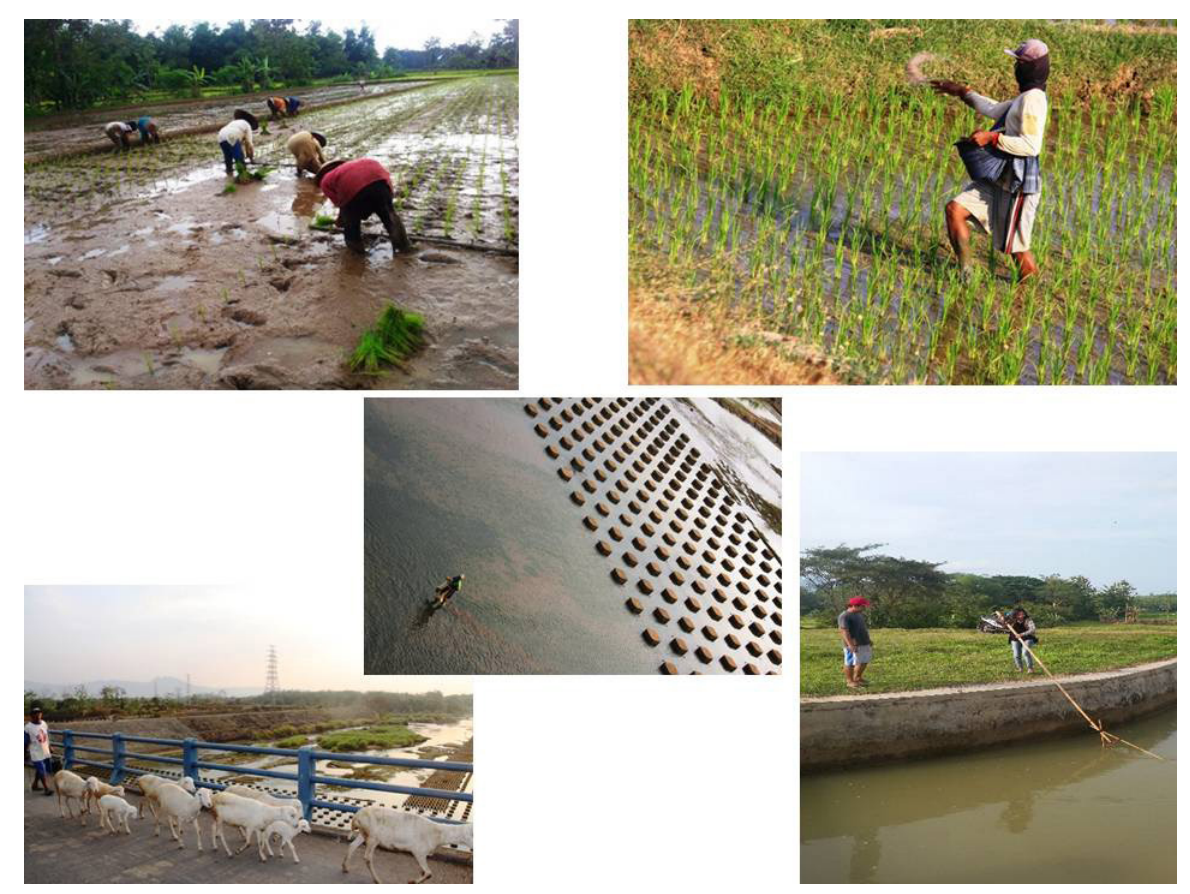

Foto 9. Kegiatan warga Desa Pengkol di sekitar Bendung Colo (Tim PKM Pengkol)

\section{Pembuatan Jaring dan Alat Penciduk Ikan}

Sebagai desa yang wilayahnya memiliki sumber alam ikan air tawar, warga Desa Pengkol ternyata banyak yang berprofesi sebagai pembuat jaring, jala dan penciduk ikan. Pusat pembuatan jaring dan penciduk ikan di Desa Pengkol terletak di Dusun Bangun Sari, RW 1, RT 4. Bapak Sarmin merupakan pembuat jaring dan penciduk ikan yang paling terkenal di seluruh Desa Pengkol. Menurut Pak Sarmin proses pembuatan jaring ditentukan oleh kerapatan dan luas jaringnya. Semakin rapat dan semakin luas jaringnya akan semakin lama pula waktu pengerjaannya. Bahan pembuat jaring dan jala ikan yang berupa senar dibeli di Wonogiri, Semarang, Delanggu, dan Klaten. Diameter senar bervariasi mulai dari 0,7-0,20 mm. Harga senar panjang $100 \mathrm{~m}$ lebih bervariasi sesuai dengan diameternya, yaitu antara Rp. 25.000 - Rp. 40.000. Pesanan pembuatan jaring, jala dan penciduk ikan mencapai puncaknya di bulan Oktober. Para pengunjung yang datang di bulan tersebut akan mendapat kesempatan melihat dan mencoba merajut serta menganyam jaring dan jala (periksa foto 10) 

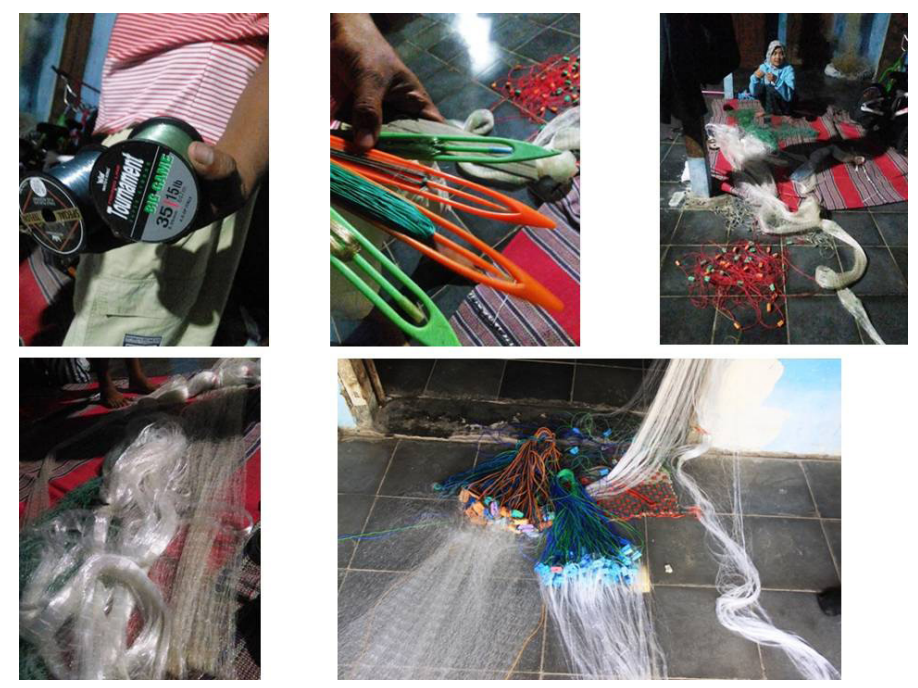

Foto 10. Proses pembuatan jaring (Tim PKM Pengkol)

\section{Aksesibilitas Desa Pengkol}

Desa Pengkol dapat dicapai dari tiga arah mata angin, yaitu jalur utara melalui jalan raya Kotamadya Solo menuju jalan Kabupaten Sukoharjo kemudian masuk ke Desa Pengkol. Jalur selatan melalui jalan Kabupaten Wonogiri kemudian masuk ke Desa Pengkol, dan jalur barat, dari jalan Kabupaten Klaten kemudian masuk ke Desa Pengkol. Angkutan umum yang tersedia untuk menuju Desa Pengkol adalah bus umum, ojek, GO-JEK dan kereta api. Titik pemberhentian bus untuk menuju Desa Pengkol adalah terminal bus Tirtonadi, Solo. Selanjutnya, perjalanan dilanjutkan dengan naik ojek, GO-JEK atau bus antar desa jurusan Solo-Nguter. Untuk mencapai Desa Pengkol, para wisatawan (dari seluruh wilayah Jawa) harus turun di stasiun pemberhentian kereta api Balapan, Solo. Selanjutnya mereka melanjutkan perjalanan dengan kereta api jurusan Solo-Wonogiri dan berhenti di stasiun kereta api Nguter.

Semua jalan menuju ke Desa Pengkol sudah diaspal halus, demikian juga jalan yang menghubungkan dusun-dusun di Desa Pengkol telah diaspal. Satu-satunya hambatan terletak pada lebar jalan yang menghubungkan dusun-dusun di Desa Pengkol. Jalan penghubung tersebut hanya dapat dilalui oleh satu mobil sehingga bila sisi kanan dan kiri jalan ada mobil, maka mobil di belakang tidak dapat mendahului mobil yang di depan. Selain itu papan petunjuk arah dan nama tempat belum ada sehingga orang yang baru pertama kali berkunjung ke Desa Pengkol harus bertanya-tanya sebelum sampai ke tempat tujuan.

\section{Amenitas Desa Pengkol}

Ketersediaan sarana dan fasilitas publik merupakan salah satu faktor pendukung keberhasilan pengembangan sebuah daerah sebagai daya tarik wisata. Observasi yang dilakukan selama berkunjung ke Desa Pengkol menunjukkan ketersediaan sejumlah amenitas, diantaranya adalah:

\section{Bank}

Sebagai calon daerah objek tujuan wisata tentu saja Desa Pengkol harus memiliki bank 
dan juga ATM untuk memudahkan wisatawan menarik uang untuk melakukan transaksi jual beli cindera mata dan membayar keperluan hidup selama tinggal di desa tersebut. Beberapa ATM dari Bank Mandiri, Bank Negara Indonesia serta ATM bersama ada di mini market Alpha Mart dan Superindo. Selain itu Bank Rakyat Indonesia juga memiliki kantor cabang di Kecamatan Nguter.

\section{Listrik}

Sumber daya listrik di Desa Pengkol dipasok oleh Perusahaan Listrik Negara (PLN). Seluruh desa Pengkol telah memiliki fasilitas listrik. Penerangan listrik pada malam hari cukup memadai di sepanjang jalan kecil antar kampung dan jalan utama pedesaan. Sumber daya listrik juga didistribusikan dengan baik kepada seluruh warga dan telah dimanfaatkan untuk berbagai keperluan sehari-hari, antara lain memasak, menyeterika, menyalakan televisi, dan lampu rumah. Keberadaan sumber daya listrik dapat dimanfaatkan untuk memenuhi keperluan wisatawan yang berkunjung dan menginap di Desa Pengkol.

\section{Air bersih}

Letak Desa Pengkol yang berada di dataran rendah, banyak pepohonan, dan dekat dengan Sungai Bengawan Solo mengakibatkan persediaan air bersih melimpah sepanjang tahun. Saat ini, hampir seluruh warga Desa Pengkol telah menggunakan sumur di halaman rumahnya untuk memenuhi kebutuhan air dengan kualitas yang baik.

\section{Telekomunikasi}

Menara-menara transmitter sarana komunikasi terdapat di berbagai tempat sekitar Desa Pengkol. Keberadaan menara tersebut memudahkan komunikasi warga Desa Pengkol dengan sanak kerabat, keluarga, dan teman, baik yang berada di desa tersebut maupun di luar desa. Semua penyedia layanan jasa telekomunikasi, antara lain Simpati, XL, M3, dan Friend dapat diakses di Desa Pengkol.

\section{Rumah Sakit}

Sarana pemeriksaan dan perawatan kesehatan di Desa Pengkol terdapat di Pusat Kesehatan Masyarakat, Kecamatan Nguter (arah barat lebih kurang $5 \mathrm{~km}$ jauhnya dari desa tersebut), Rumah Sakit Muhammadiyah Selogiri (arah selatan lebih kurang $10 \mathrm{~km}$ dan masuk wilayah Kabupaten Wonogiri), dan Rumah Sakit Umum Daerah (RSUD) Sukoharjo (arah barat lebih kurang $17 \mathrm{~km}$ jaraknya dari Desa Pengkol).

\section{Tempat Peribadatan}

Hampir seluruh warga Desa Pengkol beragama Islam sehingga di desa tersebut terdapat terdapat enam belas masjid dan empat mushola, yang dapat dipergunakan oleh warga desa untuk beribadat. Seluruh tempat peribadatan terus dibangun secara swadaya oleh warga desa.

\section{Pasar}

Pasar di Desa Pengkol hanya ada setiap 5 hari sekali berdasarkan hari pasaran Kalender Jawa (Pon, Wage, Kliwon, Legi, dan Pahing) dan lokasinya berpindah-pindah dari 
satu dukuh ke dukuh lainnya. Pasar terbesar dan terlengkap bagi warga Desa Pengkol adalah Pasar Nguter, yang jauhnya lebih kurang $5 \mathrm{~km}$ dari Desa Pengkol. Produk lokal yang mendominasi barang dagangan di pasar tersebut adalah jamu tradisional (periksa foto 11). Dinas Pariwisata Kabupaten Sukoharjo sudah mempromosikan Pasar Nguter sebagai obyek daya tarik wisata dalam brosur promosinya.

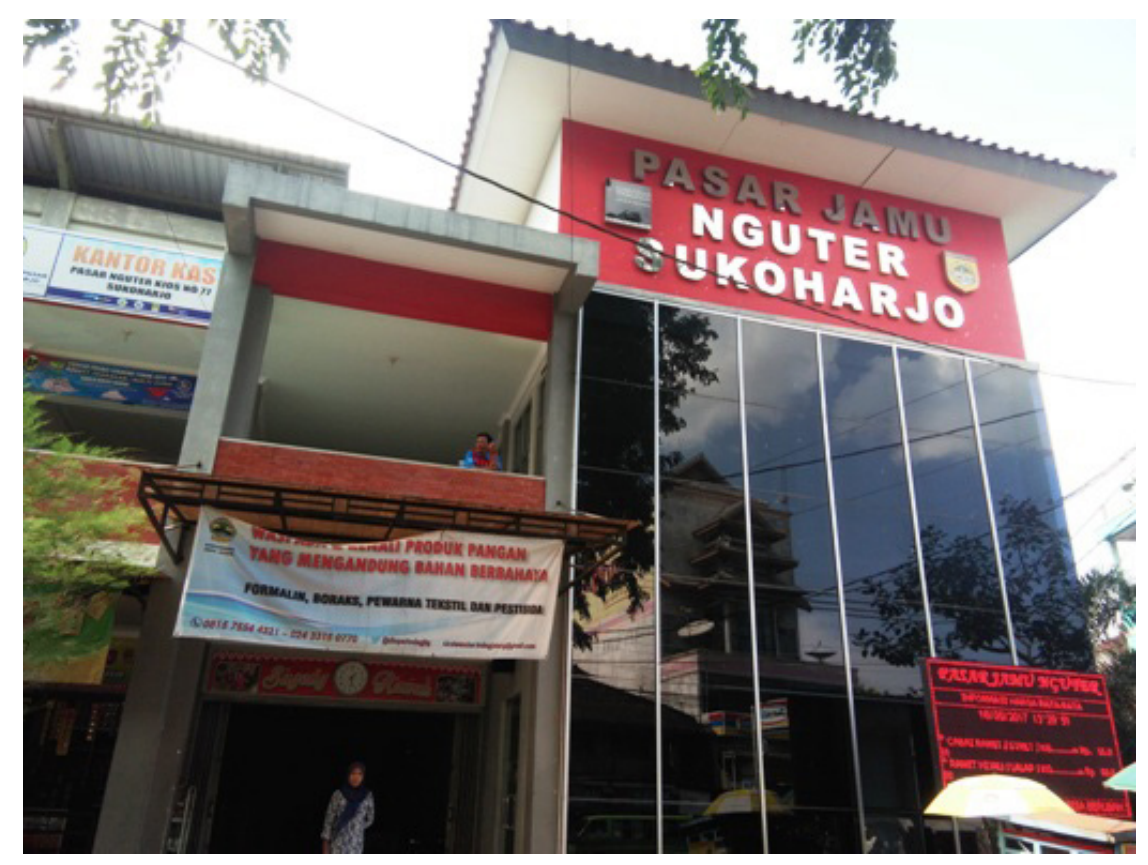

Foto 11. Pasar Nguter di Kecamatan Nguter (Tim PKM Pengkol)

\section{Pertokoan}

Pertokoan di Desa Pengkol berjumlah lebih kurang 21 buah, yang hampir seluruhnya memusat di depan jalan raya Pengkol-Sukoharjo dan di depan pertigaan jalan menuju Kantor Kelurahan Desa Pengkol. Toko-toko tersebut menjual berbagai macam barang dagangan, antara lain peralatan rumah tangga, elektronik, hp dan simcard, pakaian serta pupuk dan peralatan pertanian.

\section{Kantor Polisi dan Komando Rayon Militer}

Salah satu hal yang menyebabkan para wisatawan akan merasa nyaman di daerah tujuan wisata adalah terjaminnya rasa aman dari tindak kejahatan. Desa Pengkol memiliki kantor polisi dan kantor militer yang siap selama 24 jam untuk berjaga melindungi warga desan dan sewaktu-waktu dapat dikunjungi jika terjadi atau mengalami tindak kejahatan.

\section{Penginapan}

Sampai saat ini belum ada penginapan di Desa Pengkol, meskipun demikian ada beberapa rumah warga desa yang layak dijadikan sebagai tempat menginap bagi wisatawan (home stay) yang berkunjung ke Desa Pengkol. Fasilitas yang terdapat di dalam rumah cukup memadai, antara lain: tv, sofa, tempat tidur, air, listrik dan toilet yang bersih (periksa foto 12 dan 13) 


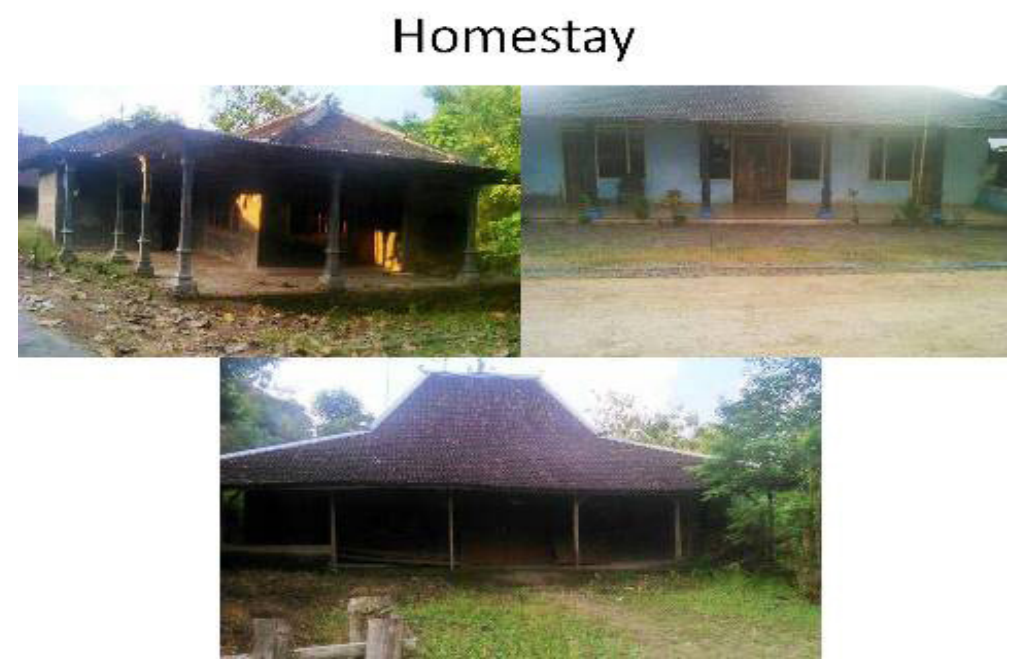

Foto 12: Beberapa home stay yang ada di Desa Pengkol (Tim PKM Pengkol)
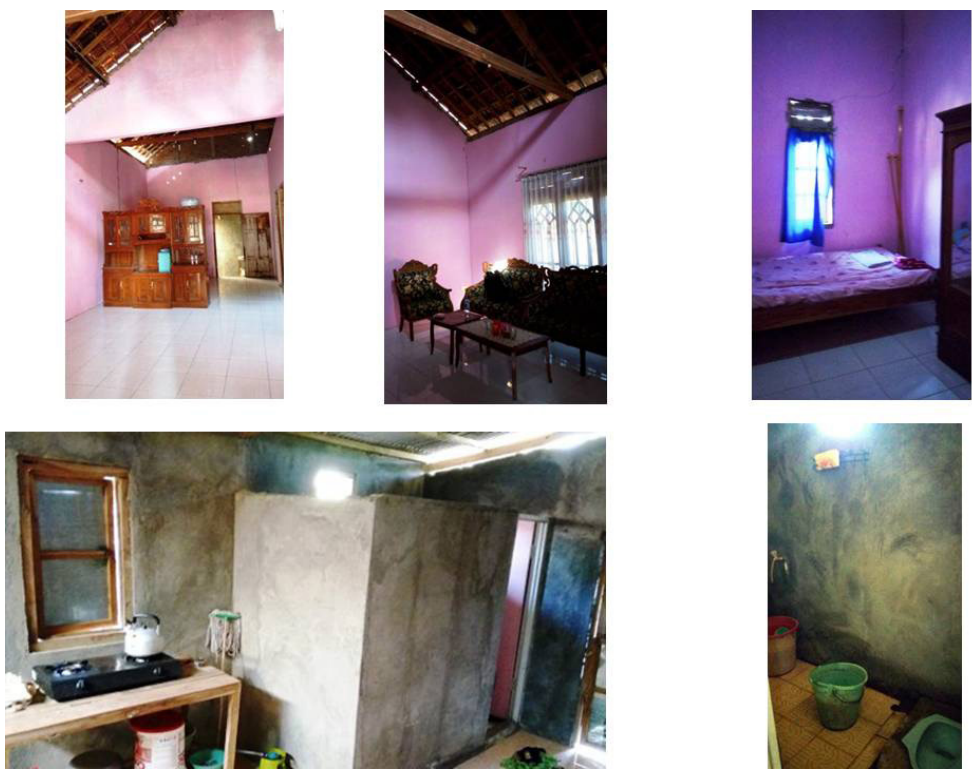

Foto 13: Fasilitas salah satu home stay (Tim PKM Pengkol)

\section{Rumah Makan}

Di wilayah Desa Pengkol terdapat beberapa rumah makan yang memiliki standar kebersihan dan kesehatan sesuai regulasi yang ditetapkan oleh Dinas Kesehatan. Standar tersebut dibuktikan dengan sertifikat yang dipasang pada dinding rumah makan. Beberapa diantaranya, yaitu Bakso Geco, Mie Ayam, Soto, dan Gendar Pecel.

\section{Amenitas Pelengkap}

Desa Pengkol yang akan menjadi objek daya tarik wisatawan harus dilengkapi dengan fasilitas tempat parkir. Lahan desa yang kurang terawat dapat dijadikan sebagai lahan parkir untuk menampung kendaraan wisatawan yang berkunjung. Area parkir yang 
dibangun harus cukup luas dan memiliki daya tampung yang cukup memadai untuk kendaraan baik roda dua maupun roda empat. Selain itu perlu disediakan kamar mandi dan toilet umum di tempat-tempat yang akan dijadikan sebagai wilayah atraksi wisata.

\section{Kelembagaan}

Selain lembaga pemerintahan desa, saat ini di Desa Pengkol terdapat pula organisasi Karang Taruna, Kelompok Tani, dan Kelompok PKK. Meskipun demikian Kelompok Sadar Wisata (Pokdarwis) belum terbentuk. Sesuai dengan regulasi di Dinas Pariwisata Kabupaten Sukoharjo, bantuan dana untuk pengembangan kegiatan pariwisata akan diperoleh jika proposal permintaan dana bantuan diajukan oleh Kelompok Sadar Wisata. Atas dasar hal tersebut pembentukan Kelompok Sadar Wisata harus dilakukan supaya pengembangan dan pengelolaan program kepariwisataan di Desa Pengkol dapat berjalan dengan lancar.

\section{Focus Group Discussion (FGD)}

Setelah kegiatan observasi potensi daya tarik wisata di Desa Pengkol selesai dilakukan, tim pengabdian masyarakat kemudian mendiskusikan selanjutnya menyeleksi potensi daya tarik wisata yang dapat dikembangkan sebagai objek daya tarik wisata. Hasil penyeleksian kemudian dibuat daftar dan akan dipresentasikan dalam forum diskusi yang akan diadakan di Gedung Serbaguna Desa Pengkol. Satu bulan sebelumnya tim pengabdian masyarakat telah mengirimkan undangan kepada Dinas Pariwisata, Kabupaten Sukoharjo, Bappeda Kabupaten Sukoharjo, Kepala Desa, Sekretaris Desa serta Perangkat Desa Pengkol, Komandan Polsek Desa Pengkol, Komandan Koramil Desa Pengkol,Karang Taruna, Pelaku usaha lokal (pedagang dan pengusaha) Desa Pengkol, petani, penangkap ikan, warga masyarakat pemilik home stay, seniman dan budayawan di Desa Pengkol.

Pada tanggal 26 Agustus jam 08.00 pagi bertempat di Gedung Serbaguna Desa Pengkol dimulai agenda forum diskusi dengan tema 'Pengembangan Potensi Kepariwisataan Berbasis Masyarakat di Desa Pengkol'. Seluruh undangan hadir dan beberapa peserta dari instansi yang diundang merupakan perwakilan dari kepala dinas yang tidak dapat menhghadiri acara ini. Sebanyak 50 orang undangan dan ditambah dengan tim pengabdian masyarakat dari Fakultas Ilmu Budaya total peserta forum diskusi menjadi 60 orang.

Acara dibuka dengan sambutan dari Sekretaris Kecamatan Nguter yang menyambut gembira dan akan membantu semaksimal mungkin dalam proses kegiatan berikutnya. Selanjutnya Kepala Desa Pengkol menyampaikan aspirasi warga Desa Pengkol yang sangat antusias untuk menjadikan desanya sebagai desa wisata. Perwakilan tim pengabdian masyarakat kemudian menyampaikan informasi tentang prasyarat pengembangan daya tarik wisata menjadi objek daya tarik wisata melalui program $4 \mathrm{~A}$, yaitu atraksi (attraction) wisata yang meliputi, sesuatu yang dapat dilihat (something to see), sesuatu yang dapat dilakukan (something to do), sesuatu yang dapat dibeli (something to buy), aksesibilitas (accessibility), amenitas (amenity), dan ansilari (ancillary)/kelembagaan. Setelah penyampaian informasi selesai dilakukan disusul dengan acara diskusi dan tanya jawab. 
Para pengusaha dan pedagang di Desa Pengkol menginformasikan bahwa Beberapa produk andalan desa juga sudah ada untuk memenuhi aspek something to buy, yaitu, produk jamu dari Kampung Jamu Nguter serta jala ikan. Di samping atraksi yang sudah disebutkan tersebut terdapat potensi wisata budaya dan wisata religi dengan ditemukannya reruntuhan Yoni dan rencana warga untuk mengadakan pengajian akbar di sekitar bendungan sekaligus sebagai upaya kontrol dari kemungkinan tindak asusila dari para pemuda yang terjadi di sekitar bendungan.

Perwakilan dari Jasa Tirta sebagai pengelola Bendung Colo menambahkan informasi bahwa pihak Bendung Colo tidak keberatan jika lokasinya akan dikembangkan sebagai objek daerah tujuan wisata, meskipun demikian pihaknya meminta agar warga desa mengeplot lokasi yang akan dijadikan sebagai atraksi wisata dan selanjutnya kepala desa membuat proposal pengembangan dan pemanfaatan lokasi wisata Bendung Colo sebagai objek daya tarik wisata. Proposal tersebut diserahkan kepada pihak pengelola Bendung Colo, yang selanjutnya akan menyerahkan kepada Kementerian Pekerjaan Umum untuk memperoleh persetujuan.

Perwakilan Karang Taruna kemudian menyampaikan masalah ketiadaan dana untuk membuat kaos cindera mata bagi para wisatawan yang mengunjungi Bendung Colo. Mereka berharap pihak Dinas Pariwisata, Kecamatan dan Kelurahan memberikan bantuan dana untuk memulai usaha penjualan cindera mata. Hal serupa juga dikemukakan oleh salah satu perwakilan dari sesepuh warga desa. Menurutnya potensi wisata budaya yang ada di Desa Pengkol cukup banyak, termasuk diantaranya adalah pertunjukan wayang kulit, gamelan, dan tari. Apabila ada dana yang dapat dipakai sebagai modal untuk pengembangan lebih lanjut kesenian tersebut upaya pengembangan potensi wisata budaya di desa tersebut akan lebih maksimal. Pihak Dinas Pariwisata kemudian menyarankan agar segera dibentuk Kelompok Sadar Wisata (Pokdarwis). Langkah yang harus ditempuh dengan cara membentuk kepengurusan Pokdarwis dan setelah organisasi terbentuk disarankan untuk segera membuat proposal program kegiatan bisnis cindera mata. Hasil diskusi kemudian dicatat dan diagendakan tindak lanjut koordinasi dengan dinas-dinas dan stake holder yang hadir dalam forum diskusi tersebut. Tepat jam 13.00 semua peserta forum diskusi menyepakati hasil rekomendasi tindak lanjut forum diskusi. Akhirnya forum diskusi ditutup dengan acara makan siang bersama (periksa foto 14).
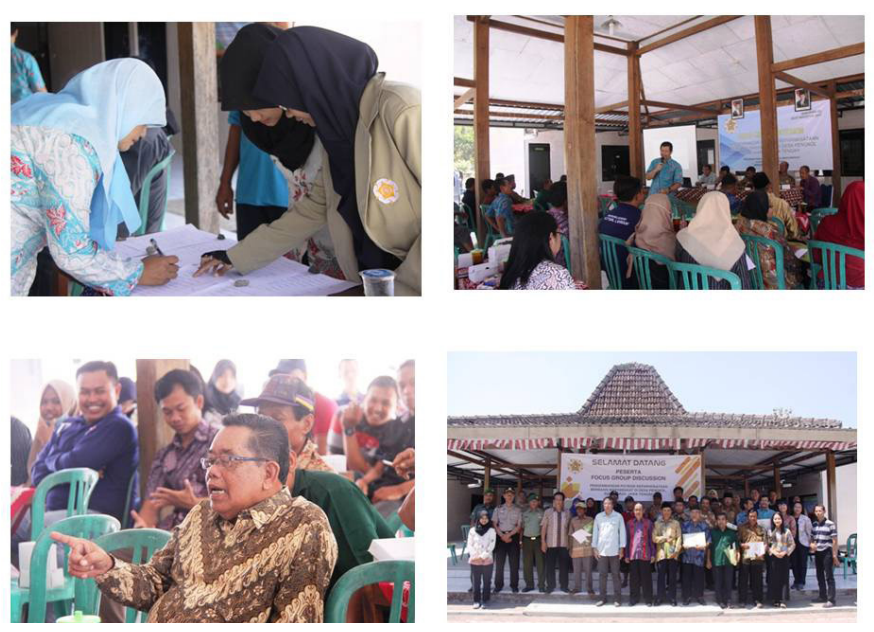

Foto 14: Suasana forum diskusi kelompok (Tim PKM Pengkol) 


\section{Rencana Tindak Lanjut Pengembangan Potensi Kepariwisataan Desa Pengkol}

Sesuai dengan kesepakatan yang diperoleh dari diskusi bersama dalam bentuk focus group discussion, program pengabdian masyarakat di Desa Pengkol yang dilakukan oleh tim pengabdian pada masyarakat dari Fakultas Ilmu Budaya akan ditindaklanjuti melalui program pengabdian kepada masyarakat secara berkelanjutan. Selain itu Program Studi Pariwisata berketetapan untuk menjadikan desa tersebut sebagai 'laboratorium' yang dapat dipergunakan sebagai lokasi praktek mata kuliah Program Studi Parwi yang berkaitan dengan minat atraksi wisata dan destinasi wisata, antara lain mata kuliah Pariwisata Berbasis Masyarakat, Ekowisata, dan Pariwisata Berkelanjutan. Selaras dengan tujuan tersebut Program Studi Pariwisata sudah merancang program kelanjutan pengabdian masyarakat jangka menengah, yang berupa perancangan dan pembuatan program paket wisata, pembentukan Pokdarwis, dan pembuatan proposal program pengembangan Desa Wisata Pengkol Selanjutnya akan disusul dengan program pemasaran yang diawali dengan membuat imej (branding) terhadap Desa Wisata Pengkol, promosi melalui sosial media, biro agen perjalanan, dan instansi Dinas Pariwisata di Propinsi Jawa Tengah. Progam jangka menengah ini direncanakan selama dua tahun. Tahap akhir jangka panjang dari program pengabdian di Desa Wisata Pengkol berupa pendampingan serta selama tahun terakhir melakukan evaluasi terhadap program paket wisata dan mengetahui tingkat kepuasan para wisatawan yang mengunjungi Desa Wisata Pengkol.

Hambatan utama yang dihadapi dalam pengembangan potensi kepariwisataan di Desa Pengkol adalah penyusunan program rencana kerja yang seringkali harus direvisi karena berbentrokan dengan kegiatan sebagian besar warga desa usia produktif, khususnya mereka yang bekerja sebagai buruh serta migran di kota-kota besar Indonesia. Peran mereka sebagai pelopor untuk mengembangkan dan mengelola potensi kepariwisataan di desa mereka sangat penting. Untuk mengatasi hal ini perlu dilakukan penyesuaian program dan jadwal pelaksanaan program. Metode grounded research yang mengakomodasi pengetahuan sebagai hasil produk sosial masyarakat yang harus dipahami dari berbagai sudut pandang sehingga pelaku dan pendamping program pengabdian masyarakat harus terus menerus melakukan refleksi terhadap tindakan, aksi dan partisipasi selama di lapangan paling tepat diterapkan untuk mengatasi hambatan bagi program pengabdian masyarakat semacam ini (Junek dan Killion 2012: 328-329).

\section{Penutup}

Pengabdian masyarakat di Desa Pengkol, Kecamatan Nguter, Kabupaten Sukoharjo, Jawa Tengah merupakan upaya para dosen di Fakultas Ilmu Budaya untuk menerapkan keahlian ilmunya sekaligus mengaplikasikannya agar dapat meningkatkan kesejahteraan warga Desa Pengkol. Melalui serangkaian program yang berkelanjutan diharapkan masyarakat setempat mampu menyerap ilmu yang dipraktekkan sehingga dapat membantu masyarakat untuk meningkatkan kesejahteraan mereka. Pengabdian masyarakat ini bersifat lintas ilmu dan multidisipliner serta melibatkan partisipasi masyarakat sejak awal hingga akhir kegiatan. Tentu saja pengabdian masyarakat ini tidak semata-mata bersifat non-akademik, tetapi setiap program pemberdayaan masyarakat berlandaskan 
pada teori-teori dan paradigma yang sedang menjadi trend di ilmu-ilmu sosial dan humaniora, khususnya ilmu pariwisata. Pengabdian masyarakat tahap pertama ini baru dapat menghasilkan temuan potensi kepariwisataan Desa Pengkol yang tsebelum program pengembangan potensi kepariwisataan di desa tersebut dilaksanakan secara berkelanjutan. Pada program pengabdian masyarakat berikutnya diharapkan tidak hanya merupakan program pengabdian masyarakat, tetapi sekaligus juga merupakan program penelitian di berbagai bidang ilmu sosial budaya, khususnya di bidang studi pariwisata berbasis masyarakat, ekowisata, dan pariwisat berkelanjutan. Apabila hal ini dapat dilakukan, tentu akan dapat mendorong munculnya perumusan teori-teori baru yang dihasilkan dari program pengabdian kepada masyarakat, demikian pula sebaliknya munculnya teori baru dapat diterapkan untuk menyempurnakan program pengabdian kepada masyarakat.

\section{Ucapan Terima kasih}

Artikel ini tidak mungkin terselesaikan tanpa bantuan dan kerjasama dari tim pengabdian kepada masyarakat Fakultas Ilmu Budaya, khususnya Dr. Wiwik Sushartami, M.A., Program Studi Pariwisata sebagai koordinator acara focus group discussion, Drs. Arif Akhyat, M.A., Departemen Sejarah sebagai observator sejarah dan tradisi lokal, Dwi Pradnyawan, S.S., M.A., Departemen Arkeologi sebagai observator peninggalan kepurbakalaan. Bekti Rizki Yanti dan Rozani Nurul Arofah mahasiswa Program Studi Pariwisata sebagai pengumpul data dan observator lapangan, Wastu Hari Prasetia mahasiswa Program Studi Pariwisata sebagai observator lapangan dan penggambar peta, Zulfina Zahara dan Hafiat mahasiswa Program Studi Pariwisata dan Khanza Putri mahasiswa Program Studi Sejarah sebagai asisten lapangan. Atas kerjasama dan bantuan selama penyelenggaraan program pengabdian kepada masyarakat di Desa Pengkol, Kecamatan Nguter, Kabupaten Sukoharjo, Jawa Tengah penulis menyampaikan ucapan terima kasih setulus hati.

\section{Daftar Pustaka}

Beeton, Sue. (2006). Community Development through Tourism. Collingwood: Landlinks Press.

Gningue, A.M. (1993). 'Integrated Rural Tourism Lower Casamance'. (Ed.) Eber, S. Beyond the Green Horizon: A Discussion Paper on the Principles for Sustainable Tourism, World Wide Fund for Nature, Godalming.

Holden, Andrew. (2006). Tourism Studies and the Social Science. London: Routledge

Jamal, Tazim dan Dredge, Dianne. (2015). 'Tourism and Community Development Issues'. (Ed.) Richard Sharpley dan David J. Telfer. Tourism and Development. Concepts and Issues $2^{\text {nd }}$ Edition. Bristol: Channel View Publication. hlm. 178-204. Junek, Olga dan Killion Les. (2012). 'Grounded Theory'. (Ed.). Dwyer, Larry, Gill, Alison dan Seetaram, Neelu. Handbook of Research Methods in Tourism: Quantitative and Qualitative Approaches. Cheltenham, UK dan Northampton, USA: Edward Elgar Publishing Limited. hlm. 325-338.

Kelurahan Desa Pengkol. (2016). Monografi Desa Pengkol. 
Scheyvens, Regina. (2015). 'Tourism and Poverty Reduction'. (Ed.) Richard Sharpley dan David J. Telfer. Tourism and Development. Concepts and Issues $2^{\text {nd }}$ Edition. Bristol: Channel'. View Publication. hlm. 118-138.

The Mountain Institute. (2000). Community Based Tourism for Conservation and Development: A Resource Kit. Washington D.C. 